\title{
Historic temperature observations on Nordaustlandet, north-east Svalbard
}

\author{
Björn-Martin Sinnhuber \\ Karlsruhe Institute of Technology, Institute of Meteorology and Climate Research, Eggenstein-Leopoldshafen, Germany
}

\begin{abstract}
Long-term meteorological data for the Arctic are sparse. One of the longest quasi-continuous temperature time series in the High Arctic is the extended Svalbard Airport series, providing daily temperature data from 1898 until the present. Here, I derive an adjustment to historic temperature observations on the island of Nordaustlandet, north-east Svalbard, in order to link these to the extended Svalbard Airport series. This includes the Haudegen observations at Rijpfjorden during 1944/45 and a previously unrecognized data set obtained by the Norwegian hunters and trappers Gunnar Knoph and Henry Rudi during their wintering at Rijpfjorden in 1934/35. The adjustment is based on data from an automatic weather station at Rijpfjorden during 2014-16 and verified with other independent historic temperature observations on Nordaustlandet. An analysis of the Haudegen radiosonde data indicates that the surface temperature observations at Rijpfjorden are generally well correlated with the free tropospheric temperatures at $850 \mathrm{hPa}$, but occasionally show the occurrence of boundary-layer inversions during winter, where local temperatures fall substantially below what is expected from the regression. The adjusted historic observations from Nordaustlandet can, therefore, be used to fill remaining gaps in the extended Svalbard Airport series.
\end{abstract}

\section{Introduction}

The Arctic climate is changing rapidly, with the Arctic rate of warming much larger than the global average warming, the so-called Arctic amplification (Stocker et al. 2013; Przybylak \& Wyszynski 2020). Although it is well established that anthropogenic emissions of greenhouse gases are the dominant drivers of the ongoing Arctic climate change, the relative contribution of different natural and anthropogenic forcings, together with internal variability of the climate system, to the observed changes over the past 100 years is still not fully understood. In particular, the observed Arctic warming during the early 20th century (Grant et al. 2009; Wood et al. 2010; Yamanouchi 2011; Xiao et al. 2020) is still not well reproduced in most climate models (Fyfe et al. 2013). It remains uncertain (e.g., Przybylak 2000, 2007) whether the early 20th century warming primarily reflects internal variability of the coupled climate system (Bengtsson et al. 2004) or if anthropogenic and natural aerosol forcings play a dominant role (Fyfe et al. 2013).

Long-term meteorological reference data for the Arctic are sparse, in particular for the early 20th century. One of the longest quasi-continuous temperature time series in

\section{Keywords}

Climate change; Arctic amplification; early 20th century warming; hunters' diaries; Henry Rudi; Oxford University Arctic Expedition 1935/36

\section{Correspondence \\ Björn-Martin Sinnhuber, Karlsruhe Institute of Technology, Institute of Meteorology and Climate Research, Hermann-von-Helmholtz- Platz 1, DE-76344 Eggenstein-Leopoldshafen, Germany. E-mail: bjoern-martin.sinnhuber@ kit.edu}

\section{Abbreviations}

AWS: automatic weather station RMSE: root mean square error UNIS: University Centre in Svalbard the High Arctic is the homogenized extended Svalbard Airport series (Nordli et al. 2014; Nordli et al. 2020). Observations have been taken at Svalbard Airport only since 1975, so they have been merged with earlier observations at other places in Spitsbergen. This approach has resulted in a time-series of daily mean temperatures from 1898 to the present (Nordli et al. 2020). To connect observations at other places with the Svalbard Airport time series, adjustments based on a linear regression have been applied. This approach has benefitted from the recent installation of AWSs at or close to the sites of historic temperature observations (e.g., Przybylak et al. 2014), so that regressions between the local and primary time series could be established.

Interruption of routine meteorological observations during World War II resulted in a gap in the extended Svalbard Airport series between August 1941 and September 1945. This is particularly unfortunate, as this gap occurred around the maximum of the early 20th century warming. There have been various military meteorological observations in Svalbard during World War II, from German as well as Allied and Norwegian operations (Blyth 1951; Elbo 1952; Selinger \& Glen 1983) that could potentially fill this gap if the original data could be 
retrieved. Here, I present an adjustment of the wellknown temperature observations from the German military weather station Haudegen from August 1944 to September 1945 (Dege 1960, 2004, 2006) to link it to the extended Svalbard Airport series. Haudegen was in Rijpfjorden, at the northern coast of Nordaustlandet, in north-east Svalbard. Nordaustlandet is the second-largest island of the Svalbard archipelago (and, in fact, the 55th largest island of the world) and largely covered by two ice caps: Vestfonna and Austfonna. The climate of Nordaustlandet is much colder than that of western Spitsbergen, which is under the influence of the relatively warm waters of the West Spitsbergen Current. Nordaustlandet, in contrast, experiences a more severe High Arctic climate. This warrants extra efforts to establish the adjustment of the Haudegen observations with the Svalbard Airport series. Unfortunately, there are only five days of overlap between the Haudegen observations and the extended Svalbard Airport series, much too short to establish an adjustment. Instead, observations taken by an AWS at Rijpfjorden $19 \mathrm{~km}$ north of the Haudegen site, operated by UNIS between 2007 and 2016, are used here to derive the adjustment between the Rijpfjorden and Svalbard Airport temperature series.

Year-round temperature observations at Nordaustlandet are very sparse. Dege (1960) refers to the Oxford University Arctic Expedition during 1935/36 (Glen 1937, 1939; Glen \& Croft 1937; Hamilton 1938, 2012) as the first yearround meteorological record at Nordaustlandet. During the International Geophysical Year, a Swedish-FinnishSwiss expedition took detailed meteorological observations at Kinnvika, Murchison Bay, Nordaustlandet, from July 1957 to August 1958 (Liljequist 1959, 1960). Just by chance, I recently discovered a year-round data set of temperature observations at Rijpfjorden for August 1934 to August 1935, recorded by the hunters and trappers Gunnar Knoph and Henry Rudi, who overwintered close to the later Haudegen site. Their diary, which includes their meteorological observations, is publicly available through the archive of the Norwegian Polar Institute (Knoph 1945), but this data set has apparently gone unnoticed by the meteorological or climate literature.

The objective of this work is to present the available year-round temperature observations at Nordaustlandet, to establish an adjustment of the Haudegen measurements to the extended Svalbard Airport series and to validate this adjustment with the other historic observations at Nordaustlandet. As the 1934/35 temperature observations are available only at 22:00 hours, the hourly Rijpfjorden AWS observations during 2014-16 are analysed to derive the diurnal temperature variation at Rijpfjorden during the individual months of the year. The Haudegen radiosonde observations during 1944/45 are analysed, with a focus on determining the extent to which low temperatures during winter are connected with boundary-layer inversions, which would decouple the surface temperatures from the free tropospheric temperatures and make these observations less representative of a larger area.

\section{Data and methods}

An overview of the temperature data sets used in this study is provided in Fig. 1 and Table 1. These are essentially all available longer-term (a year or longer) temperature time series in Nordaustlandet before the late 20th century. In recent years, a number of AWSs have been installed (at least temporarily) at various places in Nordaustlandet and on nearby islands (e.g., Pohjola et al. 2011 ; Przybylak et al. 2014). Early temperature observations from Svalbard, including from ships that travelled around Nordaustlandet in the period from 1865 to 1920 , were presented by Przybylak et al. (2016) but were limited to summer months with open sea. The first monthlong temperature series on Nordaustlandet itself was taken by the Swedish-Norwegian Arctic expedition at their Sveanor station in Murchison Bay from 30 June to 10 August 1931 (Ahlmann et al. 1933). However, Murchison Bay is located in the very west of Nordaustlandet, at the Hinlopen Strait and rather close to Crozierpynten on the Spitsbergen main island, where meteorological measurements had already been taken between August 1899 and August 1900 (Przybylak et al. 2016; Nordli et al. 2020).

\section{Knoph and Rudi, Rijpfjorden 1934/35}

The Norwegian hunters and trappers Gunnar Knoph and Henry Rudi spent 1934/35 at Rijpfjorden. Their main base was located at the innermost part of the fjord Rijpfjorden, about $8 \mathrm{~km}$ south of the Haudegen site, with subsidiary stations along both sides of Rijpfjorden, one of them right next to the later Haudegen site. A diary with meteorological observations was compiled by Knoph in March 1945 and addressed to Adolf Hoel, then director of the Svalbard and Arctic Ocean Survey, which later became the Norwegian Polar Institute (Knoph 1945). Knoph's diary contains daily temperature observations between 31 August 1934 and 9 August 1935, with the temperature readings typically given without decimal places, only occasionally at half a degree resolution. Unfortunately, no details on the instrumentation are given by Knoph (1945). For most days, observations are reported for 22:00 hours; for a few days, there are 


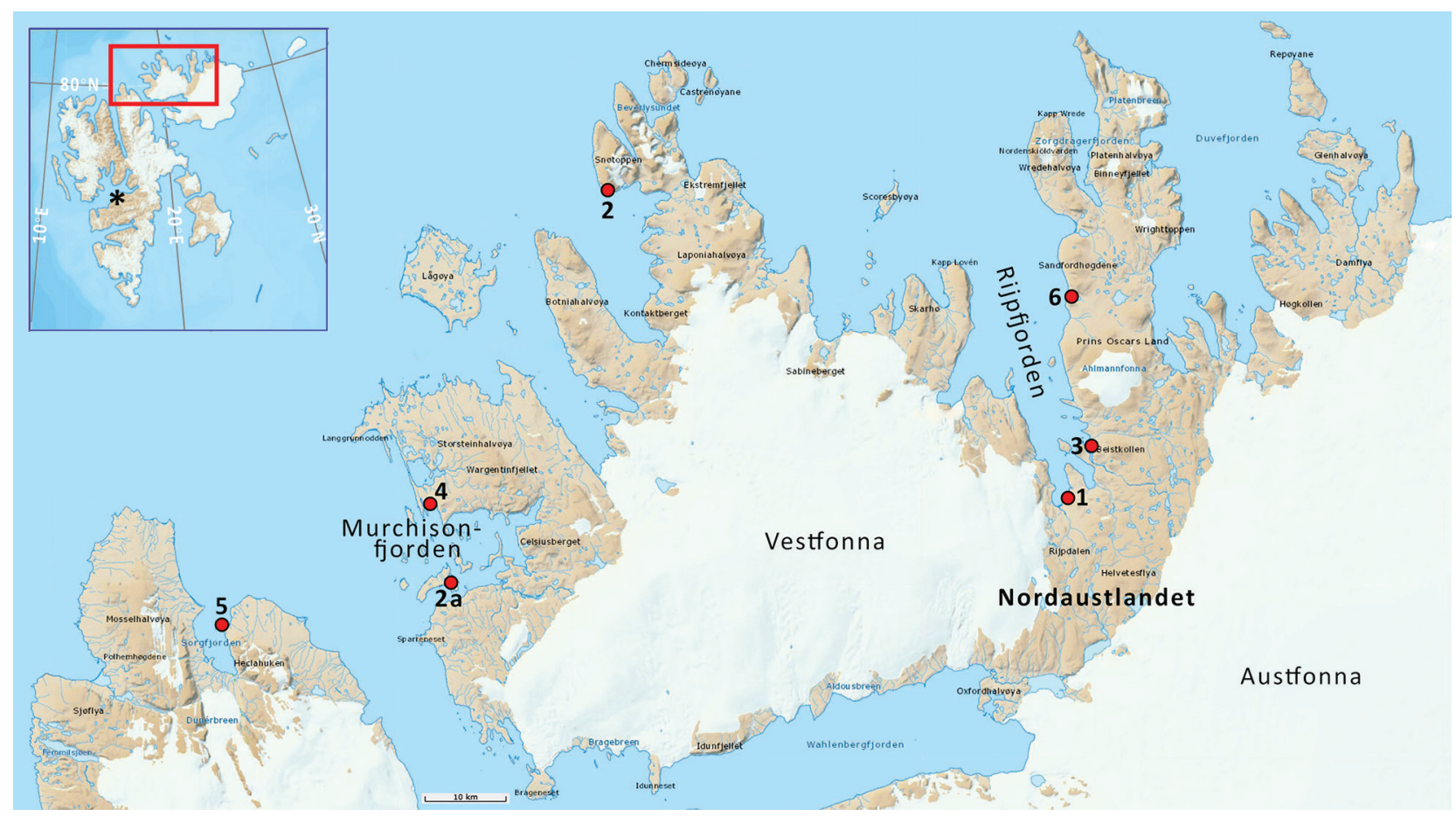

Fig. 1 Location of the temperature records considered in this study: Rijpfjorden 1934/35 (1), Oxford University Arctic Expedition 1935/36 (2/2a), Haudegen 1944/45 (3), Murchison Bay (Murchinsonfjorden) $1957 / 58$ (4), Crozierpynten AWS 2010-12 (5), Rijpfjorden AWS 2014-16 (6). Longyearbyen/Svalbard Airport is marked with an asterisk in the inset map. (Maps modified from TopoSvalbard.npolar.no.)

Table 1 Temperature time series considered in this study. All stations are at sea level.

\begin{tabular}{|c|c|c|c|}
\hline Time series & Location & Period & References \\
\hline Rijpfjorden 1934/35 & $79^{\circ} 59^{\prime} 30^{\prime \prime} \mathrm{N}, 22^{\circ} 17^{\prime} 20^{\prime \prime} \mathrm{E}$ & 31 Aug 1934-9 Aug 1935 & Knoph (1945) \\
\hline Oxford University Arctic Expedition & $80^{\circ} 23^{\prime} 05^{\prime \prime} \mathrm{N}, 19^{\circ} 29^{\prime} 16^{\prime \prime} \mathrm{E}$ & 24 Aug 1935-12 Aug 1936 & Glen (1937, 1939); Hamilton (1938) \\
\hline Oxford Expedition, Murchison Bay & $79^{\circ} 58^{\prime} \mathrm{N}, 18^{\circ} 20^{\prime} \mathrm{E}$ & 8 May 1936-31 Jul 1936 & Glen (1937); Hamilton (1938) \\
\hline Haudegen 1944/45 & $80^{\circ} 02^{\prime} 55^{\prime \prime} \mathrm{N}, 22^{\circ} 31^{\prime} 10^{\prime \prime} \mathrm{E}$ & 15 Sep 1944-5 Sep 1945 & Dege (1960) \\
\hline Rijpfjorden AWS & $80^{\circ} 13^{\prime} \mathrm{N}, 22^{\circ} 29^{\prime} \mathrm{E}$ & 17 May 2014-28 Sep 2016a & UNIS (pers. comm.) \\
\hline Murchison Bay 1957/58 & $80^{\circ} 03^{\prime} 06^{\prime \prime} \mathrm{N}, 18^{\circ} 13^{\prime} 14^{\prime \prime} \mathrm{E}$ & 19 Jul 1957-30 Aug 1958 & Liljequist (1959) \\
\hline Crozierpynten AWS & $79^{\circ} 55^{\prime} 07^{\prime \prime} \mathrm{N}, 16^{\circ} 50^{\prime} 40^{\prime \prime} \mathrm{E}$ & 11 Jul 2010-6 Jul 2012 & eKlima.met.no \\
\hline
\end{tabular}

a Some data since 25 January 2007. 'bome data from 2014 and later.

additional readings for 08:00 and 12:00. The daily temperature observations at 22:00 have been digitized here. Later in this article, I will use the hourly 2014-16 AWS data from Rijpfjorden to investigate to what extent the observations at 22:00 can be considered representative for the diurnal mean. For determining the absolute minimum and maximum temperatures at Rijpfjorden in $1934 / 35$, in addition to the 22:00 observations, the small number of readings at 08:00 and 12:00 is taken into account as well.

Nordaustlandet was never of great importance for hunting and trapping. There were a few wintering hunters and trappers on the north-west coast of Nordaustlandet in the early 20th century, but Knoph and Rudi were the only party to winter in the Rijpfjorden area (Rossnes 1993). Because of unfavourable hunting conditions on Nordaustlandet, Knoph and Rudi left Nordaustlandet in the summer of 1935 and moved to Halvmåneøya, off Edgeøya, in south-eastern Svalbard (Knoph 1945).

\section{Oxford University Arctic Expedition 1935/36}

The Oxford University Arctic Expedition to Nordaustlandet, under the leadership of Alexander ("Sandy") Glen, 
operated a main base at Depot Point at Brandy Bay (now Brennevinsfjorden), on the north-west coast of Nordaustlandet. Initially, it was planned to place the main base at Rijpfjorden, but sea-ice conditions in August 1935 prevented this (Glen 1937). Continuous meteorological observations were performed at Depot Point from 24 August 1935 to 12 August 1936 (Glen 1937; Hamilton 1938). Additional meteorological time series were taken at two ice cap stations on Vestfonna (not considered here) and at Söre Russøya in Murchison Bay (now Murchisonfjorden) from 8 May 1936 to 31 July 1936 (Hamilton 1938).

Unfortunately, there is no overlap between the Rijpfjorden time series and the Oxford expedition data at Depot Point in August 1935. Knoph and Rudi left Rijpfjorden on 11 August 1935 and paid a visit to the Oxford expedition the next day (Knoph 1945). Richard Hamilton, the meteorologist of the Oxford expedition, noted in his diary: "We had a surprise visit from two other ships, Vesteris and Isbjorn, last Tuesday [13 August; the date conflicts with that given in Knoph's account], with hunters on board who had wintered in Rijps Bay [Rijpfjorden] and told us to expect a very hard and cold winter" (Hamilton 2012: 19). In summer 1936, Glen and his company visited the place of Knoph and Rudi's former station at Rijpfjorden: "There we found the side of a hut which had been built two years before by two Norwegian hunters, Rudi and Knoph, the first ever to winter successfully in North East Land [Nordaustlandet]. Weather conditions were so severe, and hunting so poor, that in the following year they moved their huts to Edge Island [Edgeøya], 200 miles further south" (Glen \& Croft 1937: 322).

For the present study, the monthly mean temperature data of Depot Point and Murchisonfjorden were taken from Hamilton (1938). Despite some efforts, it was not possible to retrieve the original daily meteorological observations of the Oxford University expedition.

\section{Haudegen, Rijpfjorden 1944/45}

The German Navy operation known as Haudegen established the last in a series of military weather stations in Svalbard during World War II (Blyth 1951; Dege 2004, 2006). Commanded by Dr Wilhelm Dege, the base was established at the Wordie Bay (now Wordiebukta) on the eastern side of the inner Rijpfjorden in September 1944. It provided detailed three-hourly surface observations from 15 September 1944 until 5 September 1945. In total, 140 radiosondes were launched between 13 November 1944 and 18 June 1945. The original data are provided by Dege (1960). Surface temperature observations from Haudegen have previously been analysed by Przybylak et al. (2018), and upper air temperatures from
Haudegen radiosonde data were analysed by Brönnimann et al. (2012).

\section{Swedish-Finnish-Swiss expedition at Murchison Bay $1957 / 58$}

During the International Geophysical Year, the SwedishFinnish-Swiss expedition to Nordaustlandet established a base at Kinnvika, on the northern shore of Murchisonfjorden. Meteorological observations were performed between 19 July 1957 and 30 August 1958, including regular radiosonde launches (Liljequist 1959, 1960). Here, I use the monthly mean and extreme temperatures as published by Liljequist (1959). Unfortunately, I was not able to retrieve the original daily temperature observations, only a subset of the Kinnvika radiosonde observations. Upper air temperatures from radiosonde launches at Kinnvika during 1957/58 have been analysed by Brönnimann et al. (2012).

\section{AWS at Rijpfjorden}

An AWS was operated by UNIS on the eastern shore of Rijpfjorden between January 2007 and September 2016. As the early data contain many gaps, I consider only temperature observations between 17 May 2014 and 28 September 2016. The temperature data have hourly resolution; daily mean temperatures are calculated by a simple average of the hourly observations. The site of the AWS is about $19 \mathrm{~km}$ north of the historic Haudegen site.

\section{AWS at Crozierpynten}

In addition to the Rijpfjorden AWS, observations from an AWS at Crozierpynten on the northeast coast of the Spitsbergen main island are included in the present analysis. Crozierpynten is rather close to Murchison Bay, essentially separated only by the Hinlopen Strait. We may, therefore, assume that observations at Crozierpynten may be more representative for Murchison Bay than the Rijpfjorden observations on Nordaustlandet. The AWS at Crozierpynten operated continuously from 11 July 2010 to 6 July 2012. Here, I use daily mean temperature observations, obtained through eKlima.met.no.

\section{Regression with Svalbard Airport temperature series}

The present work follows the methodology of Nordli et al. (2020) for the adjustment of local temperature time series by linear regression to the Svalbard Airport series, that is, it is assumed that the two temperature series can be expressed by the linear relation 


$$
T_{s}=c_{1} T_{a}+c_{2}+\varepsilon
$$

where $T_{s}$ is the principal Svalbard Airport temperature series, $T_{a}$ is the local temperature series and $\varepsilon$ denotes the residual. The two linear coefficients, here called $c_{1}$ and $c_{2}$, are determined for each month separately. Regressions are calculated for the Rijpfjorden AWS and Crozierpynten AWS with the extended Svalbard Airport series of Nordli et al. (2020).

\section{Results and discussion}

\section{Temperature observations at Rijpfjorden}

The annual series of (unadjusted) daily temperature observations at Rijpfjorden for 1934/35, 1944/45, 2014/15 and 2015/16 are shown in Fig. 2, together with
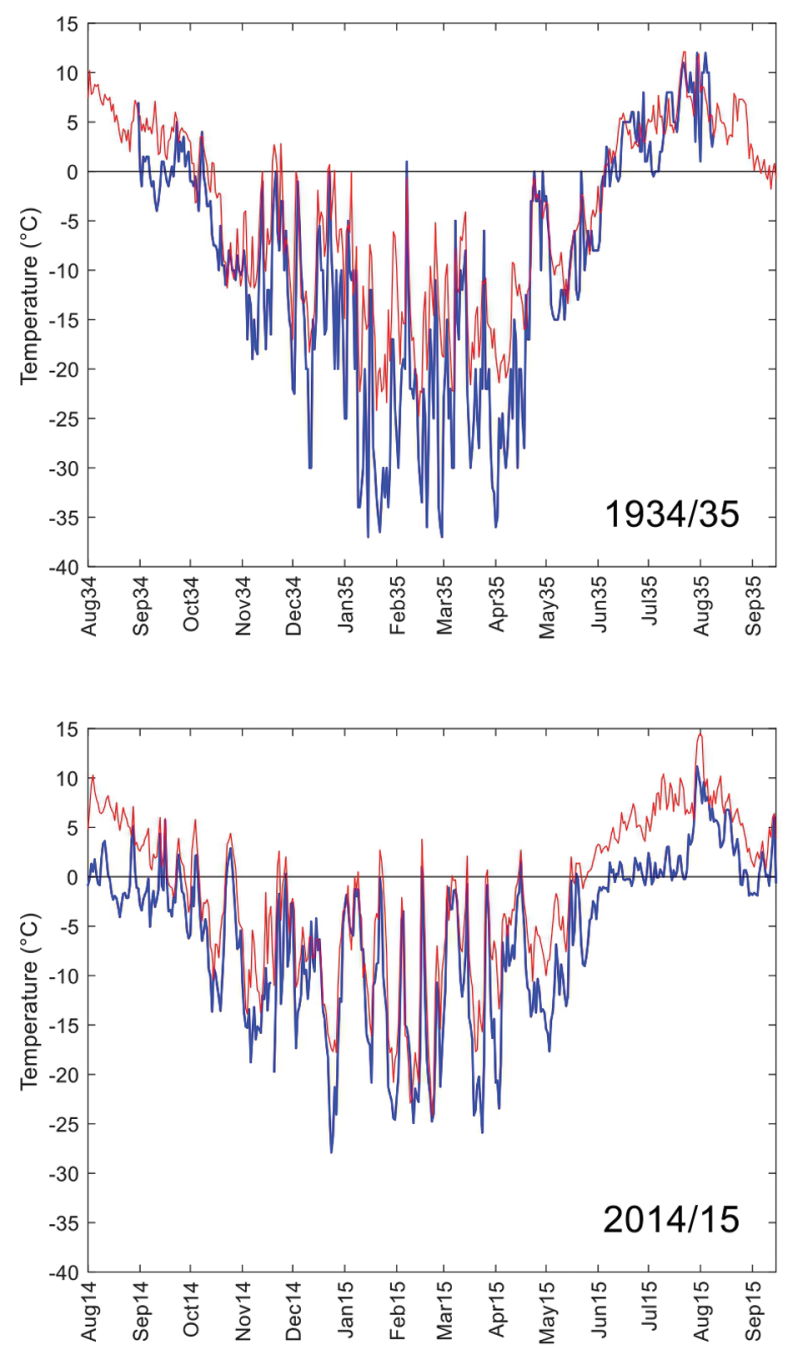

the corresponding temperatures from the extended Svalbard Airport series when available. The high degree of correlation between the temperatures at Rijpfjorden and Svalbard Airport is striking. In particular, the winter months are characterized by a very large temperature variability. Temperatures often quickly rise from very low temperature to freezing level or even above, well correlated between Rijpfjorden and the Svalbard Airport series. Correlation coefficients for winter (December to March) temperatures are 0.92 for 2014-16 and 0.80 for $1934 / 35$. Also striking is the large difference in temperatures between the cold winter of 2014/15 and the much warmer winter of $2015 / 16$. It is evident that temperatures at Rijpfjorden are typically much lower than at Svalbard Airport, in particular for the lowest temperatures in winter. Notable is the large difference between Rijpfjorden and Svalbard Airport for the coldest
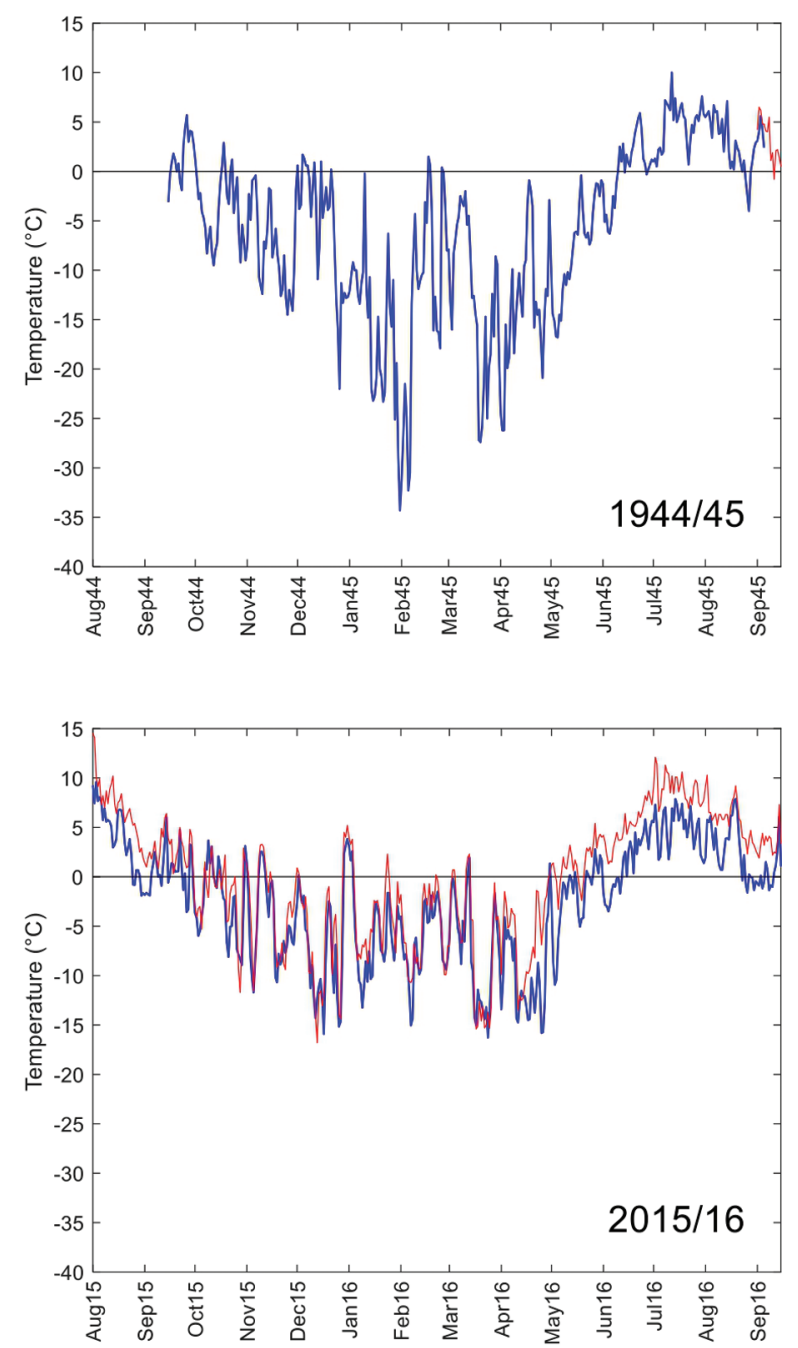

Fig. 2 Temperature observations at Rijpfjorden (blue) in comparison to the Svalbard Airport time series (red) for 1934/35, 1944/45, 2014/15 and 2015/16. Tick marks indicate the beginning of the month. 
temperatures in winter 1934/35, which calls for a more detailed analysis. Note also the large difference in summer temperatures between Rijpfjorden and Svalbard Airport for 2014-16, and the much smaller temperature differences in summer 1935.

A histogram of the Knoph (1945) temperature data shows suspicious peaks at $-10^{\circ},-20^{\circ}$ and $-30^{\circ}$ (these values about two to three times more frequent than statistically expected), raising some doubts about the accuracy of the temperature measurements. However, in general, the correlation with the Svalbard Airport series is surprisingly high (monthly correlation coefficients between 0.73 and 0.88 , except for the summer months, when also for present-day observations the correlation is weak).

Table 2 presents monthly means and maximum and minimum readings for the different data sets. The range of observed temperatures in the individual months is comparable between $1934 / 35$ and the other data sets at Nordaustlandet, but monthly means for winter 1934/35 are much colder than in any other winter. An analysis of data from the Oxford University expedition 1935/36, Haudegen 1944/45 and the present-day Rijpfjorden AWS was presented by Przybylak et al. (2018) with respect to long-term temperature trends.

Table 2 Monthly mean and extreme temperatures $\left({ }^{\circ} \mathrm{C}\right)$ from the historic data sets at Nordaustlandet. Italics indicate monthly means derived from observations that did not span a full month.

\begin{tabular}{|c|c|c|c|c|c|c|c|c|c|c|c|}
\hline Jan & Feb & Mar & Apr & May & Jun & Jul & Aug & Sep & Oct & Nov & Dec \\
\hline \multicolumn{12}{|c|}{ Monthly mean at Rijpfjorden 31 Aug 1934-9 Aug 1935} \\
\hline-24.7 & -23.5 & -21.0 & -17.7 & -9.6 & +1.7 & +5.6 & +7.1 & +0.3 & -5.8 & -10.6 & -13.8 \\
\hline \multicolumn{12}{|c|}{ Absolute minimum } \\
\hline-37.5 & -37 & -36.5 & -36 & -15 & -8 & -0.5 & +1 & -4 & -11.5 & -19 & -30 \\
\hline \multicolumn{12}{|c|}{ Absolute maximum } \\
\hline-3 & +1 & -3 & 0 & 0 & +8 & +12 & +12 & +5 & +4 & 0 & 0 \\
\hline \multicolumn{12}{|c|}{ Monthly mean at Depot Point 24 Aug 1935-12 Aug 1936} \\
\hline-12.1 & -17.1 & -24.1 & -15.8 & -2.3 & +0.7 & +2.5 & +3.8 & -2.6 & -1.8 & -5.1 & -8.8 \\
\hline \multicolumn{12}{|c|}{ Absolute minimum } \\
\hline-29.4 & -28.9 & -32.2 & -28.9 & -10.6 & -6.7 & -2.2 & -0.8 & -12.2 & -15.0 & -17.8 & -19.4 \\
\hline \multicolumn{12}{|c|}{ Absolute maximum } \\
\hline-1.1 & 0.0 & -5.6 & +1.7 & +8.3 & +11.1 & +9.4 & +9.4 & +5.6 & +6.7 & +3.3 & 0.0 \\
\hline \multicolumn{12}{|c|}{ Monthly mean at Murchison Bay 8 May-31 July 1936} \\
\hline- & & & & -2.2 & +1.1 & +4.2 & & & & & \\
\hline \multicolumn{12}{|c|}{ Absolute minimum } \\
\hline - & & & & -7.2 & -3.9 & -0.8 & & & & & \\
\hline \multicolumn{12}{|c|}{ Absolute maximum } \\
\hline- & & & & +6.9 & +6.7 & +9.4 & & & & & \\
\hline \multicolumn{12}{|c|}{ Monthly mean at Rijpfjorden 15 Sep 1944-5 Sep 1945} \\
\hline-16.1 & -11.6 & -12.5 & -13.6 & -8.2 & +0.2 & +4.8 & +2.8 & +2.1 & -3.9 & -7.7 & -5.3 \\
\hline \multicolumn{12}{|c|}{ Absolute minimum } \\
\hline-35.5 & -34.8 & -28.9 & -32.0 & -19.6 & -8.6 & -1.0 & -5.0 & -1.5 & -13.8 & -18.5 & -25.5 \\
\hline \multicolumn{12}{|c|}{ Absolute maximum } \\
\hline+0.8 & +3.5 & +0.3 & +1.0 & +3.8 & +9.0 & +13.7 & +11.0 & +7.2 & +5.3 & +2.2 & +3.2 \\
\hline \multicolumn{12}{|c|}{ Monthly mean at Murchison Bay 1 Aug 1957-30 Jul 1958} \\
\hline-11.2 & -15.8 & -18.2 & -13.6 & -4.3 & -0.3 & +2.3 & +3.7 & -0.1 & -0.9 & -8.0 & -14.4 \\
\hline \multicolumn{12}{|c|}{ Absolute minimum } \\
\hline-25.6 & -27.8 & -31.6 & -27.7 & -16.4 & -6.2 & -1.2 & -1.0 & -6.5 & -11.4 & -18.0 & -23.3 \\
\hline \multicolumn{12}{|c|}{ Absolute maximum } \\
\hline 0.0 & -3.8 & -1.4 & +3.4 & +1.0 & +6.2 & +6.4 & +9.1 & +4.9 & +3.0 & +1.1 & -1.4 \\
\hline \multicolumn{12}{|c|}{ Monthly mean at Rijpfjorden 2014-16 } \\
\hline-8.2 & -11.6 & -9.3 & -10.2 & -5.2 & +0.2 & +3.2 & +2.3 & +0.1 & -3.9 & -8.0 & -10.1 \\
\hline \multicolumn{12}{|c|}{ Absolute minimum } \\
\hline-28.4 & -28.5 & -30.3 & -27.2 & -22.0 & -7.5 & -1.9 & -5.0 & -7.8 & -18.9 & -23.4 & -32.2 \\
\hline \multicolumn{12}{|c|}{ Absolute maximum } \\
\hline+5.1 & +4.6 & +4.2 & +3.9 & +5.2 & +8.7 & +14.4 & +12.5 & +9.4 & +7.3 & +5.3 & +5.8 \\
\hline
\end{tabular}




\section{Diurnal temperature variations at Rijpfjorden}

As noted earlier, observations for 1934/35 are available only at 22:00 hours. To test the extent to which this introduces a bias compared to the daily mean, I have analysed the diurnal cycle of temperatures at Rijpfjorden from the hourly AWS measurements in 2014-16. Diurnal cycles of the temperature for individual months are shown in Fig. 3, expressed as deviations from the mean. A diurnal cycle with a peak-to-peak amplitude of up to about $2{ }^{\circ} \mathrm{C}$ becomes evident between April and November. The monthly mean diurnal cycle is, as one would expect, essentially absent during the dark winter months. The Rijpfjorden temperature measurements at 21 UTC (corresponding to 22:00 hours) are biased low with respect to the daily mean at Rijpfjorden by $-0.25{ }^{\circ} \mathrm{C}$ on average during April to September, with no significant bias during the rest of the year. In other words, the use of the 22:00 hours temperature observations instead of daily mean values introduces a negligible error compared to other sources of uncertainties. The variance increases only slightly when using the 21UTC temperature measurements instead of the diurnal averages (monthly standard deviation increases by less than $10 \%$ ), and consequently, the correlation with the Svalbard Airport time series decreases only slightly.

\section{Adjustment to the Svalbard Airport series}

Regressions between the Rijpfjorden AWS for 2014-16 with the Svalbard Airport series are given in Table 3. Correlations and RMSEs for the Svalbard AirportRijpfjorden relation are comparable or even slightly better than the Svalbard Airport-Crozierpynten relation (Nordli et al. 2020). In particular, during the summer months June, July, August, the correlation is very poor for Crozierpynten, so that Nordli et al. (2020) based the relation on the three summer months together. This was
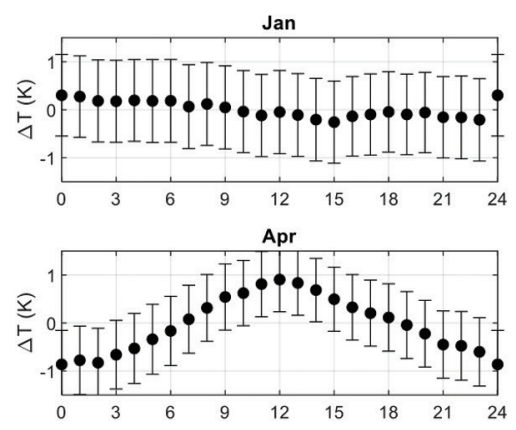

Jul

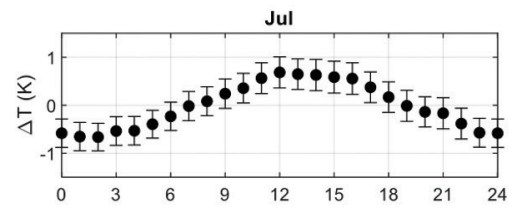

Oct

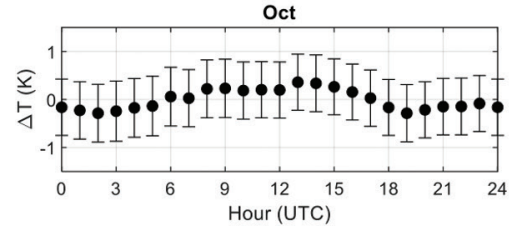

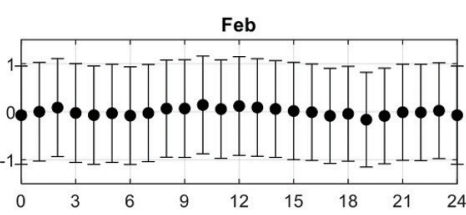

May

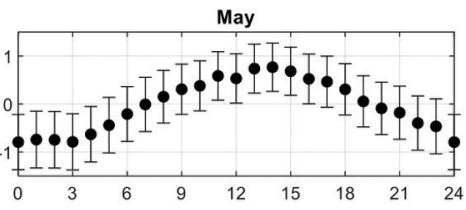

Aug

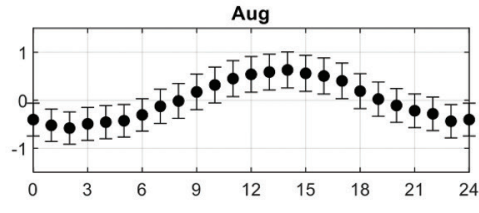

Nov

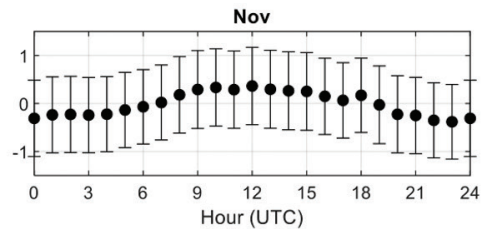

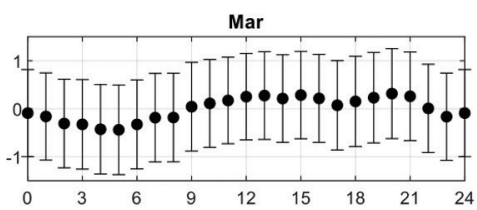

Jun

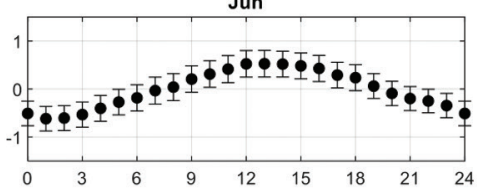

Sep

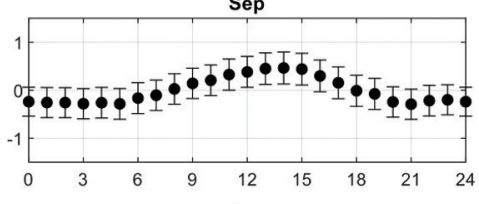

Dec

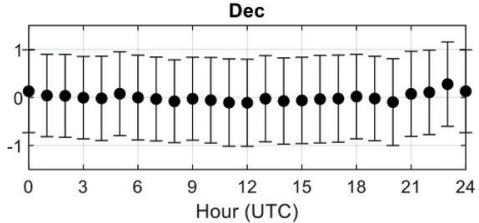

Fig. 3 Diurnal temperature variation (deviation from daily means) at Rijpfjorden for 2014-16. Error bars denote one standard error.

Table 3 Regression of temperature time series between Svalbard Airport (homogenized extended time series) and Rijpfjorden (2014-16).

\begin{tabular}{|c|c|c|c|c|c|c|c|c|c|c|c|c|}
\hline & Jan & Feb & Mar & Apr & May & Jun & Jul & Aug & Sep & Oct & Nov & $\mathrm{Dec}$ \\
\hline \multicolumn{13}{|c|}{ Svalbard Airport-Rijpfjorden (2014-16) } \\
\hline$C_{1}$ & 0.802 & 0.900 & 0.736 & 0.584 & 0.633 & 0.626 & 0.352 & 0.416 & 0.652 & 0.712 & 0.723 & 0.751 \\
\hline$C_{2}$ & 1.02 & 0.77 & -0.01 & 0.21 & 2.75 & 4.37 & 6.97 & 5.55 & 2.76 & 0.94 & 0.90 & -0.22 \\
\hline$R^{2}(\%)$ & 86 & 88 & 79 & 62 & 78 & 60 & 31 & 37 & 64 & 67 & 74 & 81 \\
\hline RMSE & 2.1 & 2.4 & 2.6 & 2.3 & 1.7 & 1.2 & 1.5 & 1.8 & 1.3 & 2.2 & 2.5 & 2.4 \\
\hline
\end{tabular}


not necessary for Rijpfjorden, although also here the correlation during July and August is rather weak.

As there is essentially no overlap between the recent AWS time series at Rijpfjorden and at Crozierpynten, we cannot directly compare the two time series, but comparing the differences with the Svalbard Airport series allows for an indirect comparison. In the annual average, the temperatures at Rijpfjorden are $1.7{ }^{\circ} \mathrm{C}$ colder than at Crozierpynten.

Using the adjustment derived from the Rijpfjorden AWS for 2014-16, we can connect the Haudegen temperature series for 1944/45 to the extended Svalbard Airport series. Table 4 presents monthly mean temperatures from October 1944 to August 1945 from the Haudegen observations, adjusted to the Svalbard Airport series. Based on the Haudegen data, July 1945 would be the warmest in the Svalbard Airport series before 2015 and August 1945 the warmest before 1998. This is in line with the fact that July and August monthly means at Rijpfjorden were much higher in 1945 than during 2015 or 2016 (Table 2). However, adjustment of summer temperatures should be treated with great caution on the account of the poor correlation during summer (only 31 and $37 \%$ of the variance explained by the regression for July and August, respectively; Table 3).

\section{Validation of adjustments}

Unfortunately, the period of five days of overlap between the Haudegen and Longyearbyen observations in September 1945 is too short to draw any meaningful conclusion. (Note that the 1945 temperature observations made in Longyearbyen predated construction of the Svalbard Airport, about $5 \mathrm{~km}$ north-west of the main settlement.) Therefore, a validation of the relation between the Rijpfjorden and Svalbard Airport temperature series is performed here by additionally comparing the adjusted monthly mean data for Rijpfjorden 1934/35, Depot Point 1935/36, Murchisonfjorden 1935/36 and Murchisonfjorden 1957/58 with the Svalbard Airport series. Table 5 presents the monthly biases, as well as the annual average bias, calculated as

$$
\Delta T=T_{s}-\left(c_{1} T_{a}+c_{2}\right)
$$

where $\Delta T$ is the temperature bias and the meaning of the other symbols as in Eqn. 1. We see that monthly mean temperatures for the winter months are biased low for 1934/35 when adjusted by the relation based on the Rijpfjorden 2014-16 observations, while temperatures are biased high in the late spring and summer. The annual average temperature bias is only $-0.2^{\circ} \mathrm{C}$. The December

Table 4 Monthly mean temperatures $\left({ }^{\circ} \mathrm{C}\right.$ ) from October 1944 to August 1945 based on measurements at Rijpfjorden (Table 2), adjusted to the Svalbard Airport series using Eqn. (1) with coefficients from Table 3.

\begin{tabular}{|c|c|c|c|c|c|c|c|c|c|c|}
\hline \multicolumn{3}{|c|}{1944} & \multicolumn{8}{|c|}{1945} \\
\hline Oct & Nov & Dec & Jan & Feb & Mar & Apr & May & Jun & Jul & Aug \\
\hline-1.8 & -4.7 & -4.2 & -11.9 & -9.7 & -9.2 & -7.7 & -2.4 & +4.5 & +8.7 & +6.7 \\
\hline
\end{tabular}

Table 5 Validation of the linear relation between Svalbard Airport temperatures and Rijpfjorden (2014-16) or Crozierpynten (2010-12), respectively, using independent historic observations. Shown is the monthly and annual mean temperature bias in ${ }^{\circ} \mathrm{C}$ between the scaled observations at Nordaustlandet (Rijpfjorden, Depot Point or Murchison Bay [Murchisonfjorden]) and the extended Svalbard Airport series.

\begin{tabular}{|c|c|c|c|c|c|c|c|c|c|c|c|c|}
\hline Jan & Feb & Mar & Apr & May & Jun & Jul & Aug & Sep & Oct & Nov & Dec & Ann. \\
\hline \multicolumn{13}{|c|}{ Rijpfjorden 1934/35, based on relation between Svalbard Airport and Rijpfjorden (2014-16) } \\
\hline-4.6 & -5.4 & -1.2 & 1.9 & 3.8 & 3.1 & 2.1 & 1.8 & -1.1 & 0.4 & -0.6 & -2.7 & -0.2 \\
\hline \multicolumn{13}{|c|}{ Depot Point 1935/36, based on relation between Svalbard Airport and Rijpfjorden (2014-16): } \\
\hline 0.9 & 2.2 & 4.0 & 3.5 & 2.1 & 3.1 & 2.9 & 1.4 & 2.7 & 0.3 & 0.2 & 1.9 & +2.1 \\
\hline \multicolumn{13}{|c|}{ Depot Point 1935/36, based on relation between Svalbard Airport and Crozierpynten (2010-12) } \\
\hline \multicolumn{13}{|c|}{ Murchison Bay 1936, based on relation between Svalbard Airport and Crozierpynten (2010-12) } \\
\hline & & & & -0.1 & 2.8 & 1.0 & & & & & & \\
\hline \multicolumn{13}{|c|}{ Murchison Bay 1957/58, based on relation between Svalbard Airport and Crozierpynten (2010-12) } \\
\hline-1.0 & -1.1 & 0.9 & 0.3 & 0.3 & 2.1 & -0.4 & 0.3 & 0.9 & -0.8 & -0.4 & 1.7 & +0.2 \\
\hline
\end{tabular}


1934 to March 1935 winter mean temperatures at Rijpfjorden were $11{ }^{\circ} \mathrm{C}$ colder than 2014-16 (Table 2), but the mean bias of the $1934 / 35$ adjusted data for December to March is only $-3.5^{\circ} \mathrm{C}$. Thus, the remaining bias of the adjustment is small (about one-third) compared to the large temperature differences. For the 1935/36 Depot Point observations, two adjustments are presented, one based on the Rijpfjorden 2014-16 observations and the other based on the Crozierpynten 2010-12 observations. In general, the adjustment based on the Crozierpynten relation works better for Depot Point than the adjustment based on Rijpfjorden: the annual average bias is $2.1{ }^{\circ} \mathrm{C}$ when using the relation based on the Rijpfjorden relation and only $0.4{ }^{\circ} \mathrm{C}$ when using the Crozierpynten relation. The $1935 / 36$ observations at Depot Point on the north-west coast of Nordaustlandet are thus apparently more in line with the observations at Crozierpynten than with those at Rijpfjorden, which is further east and further inland. The annual average temperature bias between the adjusted Murchisonfjorden series and the Svalbard Airport series for $1957 / 58$ is $0.2{ }^{\circ} \mathrm{C}$ when based on the Crozierpynten relation.

Figure 4 shows the relation between the daily Rijpfjorden measurements and the corresponding temperatures from the Svalbard Airport series for December to March for 1934/35 and 2014-16. The regression line based on the 2014-16 data is included for reference. We see that for temperatures down to about $-15{ }^{\circ} \mathrm{C}$, the 2014-16 regression also holds for the 1934/35 observations, but for lower temperatures, the 1934/35 Rijpfjorden observations are often significantly colder than expected from the present-day regression. In fact, all data can be fitted reasonably

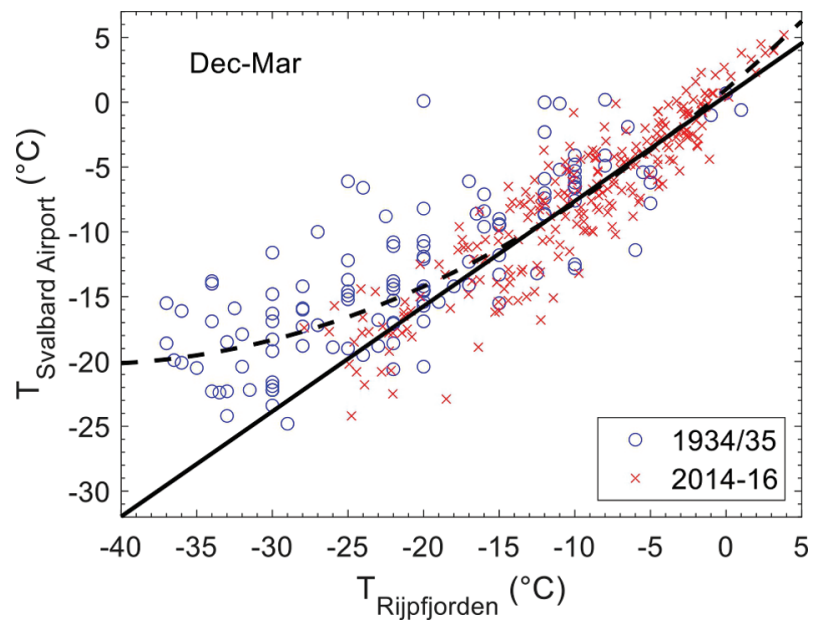

Fig. 4 Relation between Rijpfjorden and Svalbard Airport temperatures during the winter months December to March. The dashed line is a second-order polynomial fit through all data points (1934/35 and 2014-16), and the solid line represents the linear fit to the 2014-16 data only. well by a second order polynomial that agrees with the linear regression for temperatures above $-15{ }^{\circ} \mathrm{C}$. It therefore appears that for particularly cold conditions during winter the local temperatures at Rijpfjorden fall below what is expected from the linear regression, possibly as a result of the occurrence of local boundary-layer inversions that effectively decouple the local temperatures from the larger-scale variations. The use of a non-linear (second order polynomial) relation between local and primary time series is, however, problematic in that it cannot be applied to monthly mean data and is prone to unrealistic results for data outside of the fitting range. Consequently, all adjustments here are based on linear relations only.

The occurrence of boundary-layer inversions is further analysed by looking at the Haudegen radiosondes at Rijpfjorden 1944/45. Figure 5 presents the correlation between surface temperatures and $850 \mathrm{hPa}$ radiosonde temperatures (roughly 1200 m altitude). Surface temperatures are generally highly correlated with free tropospheric temperatures at $850 \mathrm{hPa}$. For winter temperatures below about $-15{ }^{\circ} \mathrm{C}$, two distributions emerge. For one distribution, surface temperatures still follow the correlation with $850 \mathrm{hPa}$ temperatures with about the same lapse rate between the surface and $850 \mathrm{hPa}$. In particular, many of the coldest temperatures in winter $1944 / 45$ are also associated with very cold conditions at $850 \mathrm{hPa}$. For the other distribution, however, we see that the surface temperatures

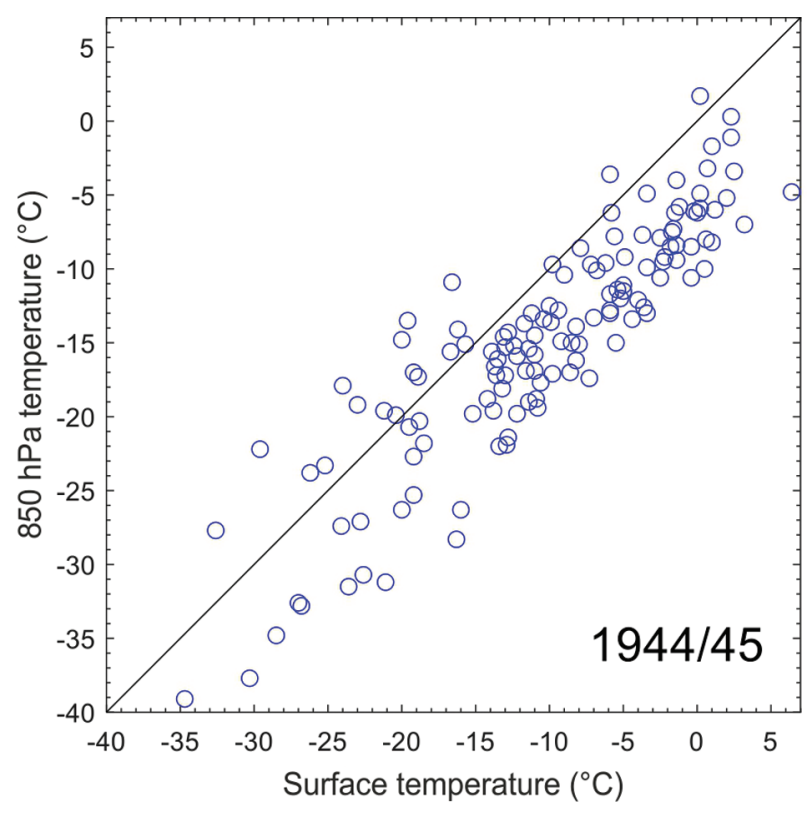

Fig. 5 Rijpfjorden 1944/45 surface temperatures against 850 hPa temperatures from radiosonde launches. Only a few of the low surface temperatures in winter are associated with boundary-layer inversions. Generally, surface temperatures are strongly correlated with $850 \mathrm{hPa}$ temperatures $\left(R^{2}=0.79\right)$. 
are substantially colder-by about $10{ }^{\circ} \mathrm{C}$ - than expected from the $850 \mathrm{hPa}$ temperatures, associated with a boundary-layer inversion. We may, therefore, speculate that the frequent occurrence of very low temperatures experienced by Knoph and Rudi in Rijpfjorden in 1934/35 is associated with those conditions of boundary-layer inversions. These boundary-layer inversions are either less frequent in later periods or they are more pronounced in the inner Rijpfjorden than at coastal sites. For example, Liljequist (1959) reports that one of their scientific objectives was to study boundary-layer inversions during winter but because of the proximity to open water during winter 1957/58 at Murchisonfjorden, inversions were not well established and, in many cases, did not exist at all.

\section{Conclusions and outlook}

The regression of the Rijpfjorden AWS with the Svalbard Airport temperature observations allows us to connect the 1944/45 Haudegen observations to the extended Svalbard Airport series. This fills at least part of the gap in the Svalbard Airport series during World War II. The quality of the regression using the Rijpfjorden observations and the associated errors are comparable to the regression for Crozierpynten or the other remote temperature series used by Nordli et al. (2020). However, during the summer months, the correlations are poor and the adjustment should be used with caution. Other available historic observations for Nordaustlandet can be used to validate this adjustment approach. Monthly mean temperature differences are comparable to what is expected from the RMSE of the regressions and are very small in the annual average but can be up to a few degrees for individual months. Comparisons of the Oxford University expedition data set at Depot Point and the Kinnvika data set indicate that these observations are more representative for the conditions at Crozierpynten than for the Rijpfjorden area in central Nordaustlandet. To the best of my knowledge, the Rijpfjorden observations in 1934/35 are discussed here for the first time in the scientific literature. Although some doubts remain about the quality of this data set, these observations indicate that winter temperatures in the Rijpfjorden area in 1934/35 were much colder than experienced by Haudegen 1944/45 or in the 21st century. This could possibly be explained by more frequent boundary-layer inversions. The Haudegen radiosonde observations generally show a strong correlation between surface temperatures and free tropospheric temperatures at $850 \mathrm{hPa}$. The lowest temperatures in winter were in many cases not restricted to the surface layer but extended up to the free troposphere. In some cases, however, surface temperatures were substantially lower than expected from the $850 \mathrm{hPa}$ observations, related to the occurrence of a boundary-layer inversion. Overall, the generally high correlation of surface with $850 \mathrm{hPa}$ observations provides further confidence that the Haudegen observations in $1944 / 45$ are generally not restricted to local conditions but may be regarded as being representative of a larger region, justifying their use to complement the extended Svalbard Airport time series.

The ultimate goal of filling the gap in the Svalbard Airport series associated with World War II would be to retrieve any meteorological observations from the Longyearbyen area during 1941-45. Meteorological observations were made by Norwegian and Allied operations (Elbo 1952; Selinger \& Glen 1983), but whether any of these original data still exist is unclear. Similarly, it would be very useful if any of the original daily temperature observations of the Oxford University expedition in $1935 / 36$ or the Kinnvika expedition in 1957/58 could be retrieved, as well as any additional temperature observations in Nordaustlandet in more recent decades. This would help to place the earlier observations at Rijpfjorden into a longer-term context and to better characterize climate change in this data-sparse High-Arctic environment.

\section{Acknowledgements}

The Rijpfjorden AWS data were provided by UNIS. The author thanks Marius Jonassen for his help. Crozierpynten AWS data and the extended Svalbard Airport series were obtained from the Norwegian Meteorological Institute through eKlima.met.no. Susan Strahan (US National Aeronautics and Space Administration's Goddard Space Flight Center/Universities Space Research Association) advised on some points of language, and Øyvind Nordli (Norwegian Meteorological Institute) and one anonymous reviewer provided helpful comments on the manuscript. The map in Fig. 1 is based on the Norwegian Polar Institute's map website, TopoSvalbard.

\section{Disclosure statement}

The author reports no conflict of interest.

\section{Funding}

BMS was funded by the German Helmholtz Society through the Atmo programme. The author acknowledges support by the KIT-Publication Fund of the Karlsruhe Institute of Technology. 


\section{References}

Ahlmann H.W., Eriksson B.E., Ångström A. \& Rosenbaum L. 1933. Scientific results of the Swedish-Norwegian Arctic expedition in the summer of 1931. Part IV-VIII. Geografiska Annaler 15, 73-216, doi: 10.2307/519460.

Bengtsson L., Semenov V.A. \& Johannessen O.A. 2004. The early twentieth-century warming in the Arctic-a possible mechanism. Journal of Climate 17, 4045-4057, doi: 10.1175/1520-0442(2004)017<4045:TETWIT>2.0.CO;2.

Blyth J.D.M. 1951. German meteorological activities in the Arctic, 1940-1945. Polar Record 6, 185-226, doi: 10.1017/ S0032247400040596.

Brönnimann S., Grant A.N., Compo G.P., Ewen T., Griesser T., Fischer A.M., Schraner M. \& Stickler A. 2012. A multidata set comparison of the vertical structure of temperature variability and change over the Arctic during the past 100 years. Climate Dynamics 39, 1577-1598, doi: 10.1007/ s00382-012-1291-6.

Dege W. 1960. Wissenschaftliche Beobachtungen auf dem Nordostland von Spitzbergen 1944-1945. (Scientific observations on Spitsbergen's Nordaustlandet 1944-1945.) Berichte des Deutschen Wetterdienstes 72. Offenbach, Germany: Deutscher Wetterdienst.

Dege W. 2004. War north of 80: the last German Arctic weather station of World War II. Boulder: University Press of Colorado.

Dege W. 2006. Gefangen im arktischen Eis: Wettertrupp "Haudegen"-die letzte deutsche Arktisstation des Zweiten Weltkrieges. (Captured in the Arctic ice: weather troop "Haudegen"- the last German Arctic weather station of World War II.) Hamburg: Convent.

Elbo J.G. 1952. The war in Svalbard, 1939-1945. Polar Record 6, 484-495, doi: 10.1017/S0032247400047276.

Fyfe J.C., von Salzen K., Gillet N.P., Arora V.K., Flato G.M. \& McConnell J.R. 2013. One hundred years of Arctic surface temperature variation due to anthropogenic influence. Scientific Reports 3, article no. 2645, doi: 10.1038/srep02645.

Glen A.R. 1937. The Oxford University Arctic Expedition, North East Land, 1935-36. The Geographical Journal 90, 193-222, doi: 10.2307/1787611.

Glen A.R. 1939. The glaciology of North East Land. Geografiska Annaler 21, 1-38, doi: 10.1080/20014422.1939.11880668.

Glen A.R. \& Croft N.A.C. 1937. Under the Pole Star-the Oxford University Arctic Expedition, 1935-6. London: Methuen.

Grant A.N., Brönnimann S., Ewen T., Griesser T. \& Stickler A. 2009. The early twentieth century warm period in the European Arctic. Meteorologische Zeitschrift 18, 425-432, doi: 10.1127/0941-2948/2009/0391.

Hamilton R.A. 1938. The Oxford expedition to North East Land, 1935-36. General meteorology. Quarterly Journal of the Royal Meteorological Society 64, 241-252, doi: 10.1002/ qj.49706427504.

Hamilton R.A. 2012. Arcticjournal Northeastland (Nordhauslandet [sic]) 1935-36. Norfolk, UK: Salt Publishing.

Knoph G.K. 1945. Rypefjorden 1934/35. Nordaustlandet, Svalbard. Handwritten journal accessed on the internet at https:// brage.npolar.no/npolar-xmlui/handle/11250/2426467 on 21 July 2020
Liljequist G.H. 1959. Murchison Bay-den svensk-finskschweiziska expeditionen till Nordostlandet 1957-58. (Murchison Bay-the Swedish-Finnish-Swiss expedition to Nordaustlandet 1957-58.) Ymer 79(2), 81-139.

Liljequist G.H. 1960. Arktisk utpost-berättelsen om den svenskfinsk-schweiziska expeditionen till Nordaustlandet 1957-1958. (Arctic outpost-the story of the Swedish-Finnish-Swiss expedition to Nordaustlandet 1957-58.) Stockholm: Forum.

Nordli Ø., Przybylak R., Ogilvie A.E.J. \& Isaksen K. 2014. Long-term temperature trends and variability on Spitsbergen: the extended Svalbard Airport temperature series, 1898-2012. Polar Research 33, article no. 21349, doi: 10.3402/polar.v33.21349.

Nordli Ø., Wyszynski P., Gjelten H.M., Isaksen K., Łupikasza E., Niedźwiedź T. \& Przybylak R. 2020. Revisiting the extended Svalbard Airport monthly temperature series, and the compiled corresponding daily series 1898-2018. Polar Research 39, article no. 3614, doi: 10.33265/polar.v39.3614.

Pohjola V.A., Kankaanpää P., Moore J.C. \& Pastusiak T. 2011. The International Polar Year Project 'KINNVIKA'-Arctic warming and impact research at $80^{\circ}$ N. Geografiska Annaler, Series A 93, 201-208, doi: 10.1111/j.1468-0459.2011.00436.x.

Przybylak R. 2000. Temporal and spatial variation of air temperature over the period of instrumental observations in the Arctic. International Journal of Climatology 20, 587-614, doi: $\quad 10.1002 /($ SICI) 1097-0088(200005)20:6<587::AIDJOC480>3.0.CO;2-H.

Przybylak R. 2007. Recent air-temperature changes in the Arctic. Annals of Glaciology 46, 316-324, doi: 10.3189/172756407782871666.

Przybylak R., Araźny A., Nordli Ø., Finkelnburg R., Kejna M., Budzik T., Migała K., Sikora S., Puczko D., Rymer K. \& Rachlewicz G. 2014. Spatial distribution of air temperature on Svalbard during 1 year with campaign measurements. International Journal of Climatology 34, 3702-3719, doi: 10.1002/joc.3937.

Przybylak R. \& Wyszynski P. 2020. Air temperature changes in the Arctic in the period 1951-2015 in the light of observational and reanalysis data. Theoretical and Applied Climatology 139, 75-94, doi: 10.1007/s00704-019-02952-3.

Przybylak R., Wyszynski P., Nordli Ø. \& Strzyziewski T. 2016. Air temperature changes in Svalbard and the surrounding seas from 1865 to 1920. International Journal of Climatology 36, 2899-2916, doi: 10.1002/joc. 4527.

Przybylak R., Wyszynski P. \& Woźniak M. 2018. Air temperature conditions in northern Nordaustlandet (NE Svalbard) at the end of World War II. International Journal of Climatology 38, 2775-2791, doi: 10.1002/joc.5459.

Rossnes G. 1993. Norsk overvintringsfangst på Svalbard 18951940. (Norwegian overwintering harvest in Svalbard 18951940.) Meddelelser 127. Oslo: Norwegian Polar Institute.

Selinger F. \& Glen A. 1983. Arctic meteorological operations and counter-operations during World War II. Polar Record 21, 559-567, doi: 10.1017/S0032247400021963.

Stocker T.F., Qin D., Plattner G.K., Tignor M., Allen S.K., Boschung J., Nauels A., Xia Y., Bex B. \& Midgley B. (eds.) 2013. Climate change 2013: the physical science basis. 
Contribution of Working Group I to the fifth assessment report of the Intergovernmental Panel on Climate Change. Cambridge: Cambridge University Press.

Wood K.R., Overland J.E., Jónsson T. \& Smoliak B.V. 2010. Air temperature variations on the Atlantic-Arctic boundary since 1802. Geophysical Research Letters 37, L17708, doi: 10.1029/2010GL044176.
Xiao H., Zhang F., Miao L., Liang X.S., Wu K. \& Liu R. 2020. Long-term trends in Arctic surface temperature and potential causality over the last 100 years. Climate Dynamics 55, 1443-1456, doi: 10.1007/s00382-020-05330-2.

Yamanouchi T. 2011. Early 20th century warming in the Arctic: a review. Polar Science 5, 53-71, doi: 10.1016/j. polar.2010.10.002. 